\title{
"Nitheroy, Revista Brasiliense (1836): A Political Bridge Between Rio de Janeiro, Paris, and Hispanic America"
}

\section{Marcelo Lotufo}

Brown University

\begin{abstract}
Nitheroy: Revista Brasiliense de sciencias, lettras, e artes (Paris, 1836), is usually taken as the starting point of Brazil's Romantic movement. The magazine, however, was primarily concerned not with literature but with the "modernization" of a recently independent Brazil. This essay focuses on the magazine in order to understand the role of literature in early nineteenth-century Brazilian politics. Approaching Brazilian Romanticism as inherently political serves to link nineteenth-century Brazilian literature to other Latin American literary movements of the period, and a re-examination of Nitheroy helps to bridge the gap that has historically separated Brazilian and other Latin American Romantic movements.
\end{abstract}

Keywords: Romanticism, Latin America, Brazil, Gonçalves de Magalhães, literature and politics

The magazine Nitheroy, revista Brasiliense de sciencias, lettras, e artes has a special place within nineteenth-century Brazilian literature. ${ }^{1}$ Published in 1836 in Paris by Domingos José Gonçalves de Magalhães (1811-1882), Francisco de Sales Torres Homem(1812-1876), and Manuel de Araujo Porto-Alegre (18061879), and aimed at a Brazilian audience, Nitheroy was a sign of the changes Brazil had begun to experience after its independence in 1822. Though only two volumes were published, the magazine became a landmark in Brazilian intellectual life and a reference point for an entire generation of intellectuals who helped to modernize Brazilian society. Nitheroy was also the platform 
from which Brazilian Romanticism was launched, as several critics and literary historians, ranging from Sílvio Romero to Afrânio Coutinho and Antonio Candido, have pointed out. That is, Nitheroy was one of the first programmatic signs that Brazilian literature was shifting away from the neoclassical paradigms that had dominated the eighteenth century and moving toward a new imaginary based on a French Romantic mindset largely indebted to Madame de Staël (17661817) and François-René de Chateaubriand (1768-1848). This was an imaginary that, not by chance, emphasized Brazil's independence, the country's specificities (i.e., its landscape, native inhabitants and tropical climate), and the importance of originality or "genius" for the development of a national spirit (to use a nineteenth-century term) and literature. It was in the first volume of the magazine that Gonçalves de Magalhães published his Romantic manifesto, "Ensaio sobre a história da literatura do Brasil: estudo preliminar," which summarized the group's impulse to modernize the country's literature and programmatically aligned Brazilian letters with French Romanticism.

The importance of Magalhães's manifesto for Brazilian Romanticism has cast a long shadow over the magazine. In this regard, literary historians have tended to limit themselves to discussing this one essay and have generally ignored the fact that Nitheroy, which featured essays on several topics, ranging from economics to travel accounts, was not primarily a literary magazine. ${ }^{2}$ Maria Orlanda Pinassi has in fact proposed that we read Nitheroy "sociologically," that is, as an important document for understanding nineteenth-century Brazil more broadly, including the shallowness of the modernization proposed by the Brazilian ruling class-a class that, while superficially aligning itself with the bourgeois "Romantic" revolutions of Europe, was nonetheless a land- and slave-owning elite who fought for the continuation of the status quo and its aristocratic privileges. Though nominally interested in the bourgeois revolutions of Europe, early nineteenth-century Brazilian elites were not bourgeois themselves, and they opposed drastic changes such as those proposed by the very revolutions they praised. As Roberto Schwarz has shown, the Brazilian elites' liberal ideology was always somewhat misplaced, for the basic aspects of life in a capitalistic society, production and labor, were dependent on slavery for most of the nineteenth century. Following Pinassi, I argue that accounting 
for the magazine's sociopolitical dimensions contributes to a better understanding of the complex links between Romanticism as a literary movement and the political tensions that led to and followed Brazilian independence.

Pinassi emphasizes the non-literary aspects of Nitheroy in order to discuss the superficiality of nineteenth-century Brazilian ideological life. My intention in reading Nitheroy, however, is to understand the relationship between the literary and non-literary aspects of the magazine. As a microcosm of the debates taking place in early nineteenth-century Brazil, the magazine is a privileged place for such a project. Its multidisciplinary and generalist nature can help us to see better how the literary discourse of nineteenth-century Brazil followed the same patterns as the discourses of other disciplines such as politics, commerce, and the sciences. It is also worth noting the superficiality of these discourses that, while in a first moment reproduced the language of caesura typical of the French Revolution and of European Romanticism, soon showed themselves to be more interested in continuity; this is made apparent by their shift to a more moderate tone after the foundation of the Instituto Histórico e Geográfico Brasileiro in 1838 and the official support of their projects by the Brazilian imperial government. During their first years, however, the discursive tone was still one of bravado. Moreover, a comparative analysis of the texts in the magazine suggests that Brazilian Romanticism was not primarily an aesthetic movement but rather a political one. In the end, relating Nitheroy's aesthetic and literary concerns to ideas on modernization, economics, religion etc. leads to a better appreciation of literature's role in nineteenthcentury Brazil not only as a validation of the country's independence but also as an endorsement of certain political positions. In addition to highlighting Brazilian Romanticism as a primarily political movement, I also argue that Brazilian Romanticism, like its counterparts in other countries of the continent, was part and parcel of the nation-building process that defined nineteenth-century Latin America as a whole. Even if in Imperial Brazil the politics of the lettered elites were at times more aligned with the official State project than was the case in most of Hispanic America, where republican intellectuals were in direct conflict with their caudillos, this does not mean Brazilians were any less political, but only that their politics worked in more subtle and silent ways than in other 
parts of the continent. Moreover, Nitheroy, which was published before the stability that came with the Second Empire and the IHGB, is much closer in tone to Romanticism in the rest of Latin America than are later developments in Brazil.

As a miscellany that covered many different themes, Nitheroy was intended to contribute broadly to the formation of a national intelligentsia in Brazil. It included essays on every topic that could be of interest to the country's elite and that, in one way or another, could advance the country in the direction its editors envisioned for the recently independent nation. The magazine, according to Pinassi, was conceived along the lines of the French Journal des connaissances utiles (1830) and the Journal de l'Institut Historique (1834) and had similarities to the Portuguese Panorama, which would be published by Alexandre Herculano in Lisbon in 1837.

It is curious that, for a magazine usually taken as the starting point of Brazilian literary Romanticism, Nitheroy includes only two texts on literature within an otherwise heterogeneous corpus. The Brazilian magazine does not resemble, for instance, the German magazine Atheneaum (1798-1800), which, according to Jean Luc Nancy and Philippe Laccoue-Labarthe, is the foundational journal of Jena Romanticism, with a clear aesthetic and philosophical inclination. The editorial and content differences between these two publications are representative, however, of the different contexts of Brazilian and German Romanticism. The German magazine of the Jena group, given the group's goal of rethinking literature's relation to philosophy and aesthetics, and their professionalization and consequent specialization (that is, their relation to the German university system), takes a direction unimaginable in Brazil. Atheneaum restricts itself to literary and aesthetic discussions, publishing translations, poems, aesthetic treaties, articles etc. In early and mid nineteenth-century Brazil, as well as in Latin America as a whole, this specialization would not be viable. In a country where the higher education system was limited to only a few law and medical schools, and where the national intelligentsia was still incipient, such a division of intellectual labor would be misplaced, and a specialized literary and philosophical magazine would not find a public or, for that matter, authors. In the absence of a strong university system, of a dynamic art market, or of an established aristocracy, artists and intellectuals tended to 
be engaged in multiple activities. Magalhães, for instance, was not just the official poet of Dom Pedro II's government but was also a member of the state bureaucracy, a doctor, a diplomat, and a politician. Similarly to Magalhães, José de Alencar, the most accomplished and popular writer of Brazilian Romanticism, dedicated himself to journalism and to a political career. Trying to understand Romanticism as an exclusively aesthetic movement, then, is a one-sided approach that ignores the cultural reality of nineteenth-century Brazil and reflects, rather, the emphasis in contemporary literary historiography on literature's autonomy from other areas.

The comparison between Nitheroy and the Atheneaum shows how, from the moment it rose, Brazilian Romanticism was not and could not be a primarily aesthetic and literary phenomenon as it had been in Germany. It was, instead, part of a larger political movement and in constant negotiation with several other areas. This is not to say that German and French Romanticism were apolitical; rather, as Friedrich Schlegel makes clear in fragment 216 of the Atheneaum, even if the aesthetic, epistemological, and political revolutions of the late eighteenth century were but one, the emphasis for him should still be on the spirit and not on realpolitik or the material development of his country, as was usually the case in Latin America. In Schlegel's own words: “The French Revolution, Fichte's philosophy, and Goethe's Meister are the greatest tendencies of the age. Whoever is offended by this juxtaposition, whoever cannot take any revolution seriously that isn't noisy and materialistic, hasn't yet achieved a lofty, broad perspective on the history of mankind" (190). That is, for Schlegel the quiet revolution of the spirit and of the subject was the privileged locus of the Romantic experience. The different perspective taken by Nitheroy, however, is made clear by the opening remarks of the first volume of the magazine. The editors of the magazine leave no doubt as to the generalist character of the magazine and their broad modernizing goal. In the prologue to the reader at the start of the first volume, they state their "desejo de ser útil aos seus concidadãos" and to "refletir sobre objetos do bem comum, e de Glória da pátria," addressing "todas as matérias, que devem merecer séria atenção do Brasileiro amigo da Glória nacional." The nationalism of the period also comes to the fore in the editorial remarks as well as in the epigraph that appears on the title 
page: “Tudo pelo Brasil e para o Brasil." Moreover, unlike Atheneaum, Nitheroy's stated intention was not to start a philosophical and literary revolution, but to help the country modernize itself (even if superficially, as Pinassi has pointed out) and to inform its readers about topics that could contribute to the country's development. In doing so, the magazine hoped to help newly independent Brazil find its way towards the already developed nations. For Nitheroy's editors, literature was only a small part of this process. Along these lines, four general topics seem representative of the magazine's intentions and are recurrent in all the areas covered by Nitheroy, including literature: 1) a critique of colonialism; 2) a turn towards France; 3) the necessity to modernize Brazil; and 4) the need to pay closer attention to the country's specificities. It is important to note that all four topics have some relation to the rising nationalism of the period and to the necessity of creating a sense of national unity, which the Brazilian elites took as their political mission as they aimed for the consolidation of the Brazilian nation-state (Schwarz 125-56).

But what are these non-literary texts that make up the bulk of essays published in Nitheroy? Besides Magalhães's literary manifesto, the magazine's volumes contain articles on topics ranging from astronomy to international commerce and sugar production. José Joaquim da Cunha Azeredo Coutinho, for instance, published in the first volume of the magazine a text titled, "Astronomia dos cometas" focusing on natural sciences and, more specifically, on the effects comets have on the daily lives of men and women. Torres Homem, also in the first volume of Nitheroy, published "Considerações Econômicas sobre a Escravatura" and, in the second, "Reflexões sobre o crédito público" and "Comércio do Brasil," both concerned with the economic development of Brazil. Antônio de Souza Lima de Itaparica published one of three texts on sugar production and commerce in the second volume of the magazine. And the painter and future diplomat Manuel de Araújo Porto-Alegre published "Ideias Sobre a Música," in the first volume, as well as a long travel description, "Contornos de Nápoles," followed by a descriptive travel poem about Italy written by himself, in the second volume. Moreover, the magazine also includes in its first volume a short presentation of its project written by its editors ("Ao leitor") and in the second volume offers a laudatory commentary on the first volume authored 
by Eugène de Monglave, then president of the Parisian Institute of History (of which all three editors of Nitheroy were members) and with a large interest in Brazil. The magazine also featured book reviews, with emphasis on the enthusiastic review of Magalhães's Suspiros Poéticos e Saudades, usually considered the first book of Brazilian Romantic poetry, a clear sign of the editors' intent to modernize Brazilian literature. Finally, the second volume of Nitheroy closes with a note of thanks to its readers and supporters, attributing its abrupt cessation to "motivos superiores," (II, 261). As Pinassi explains, the conflict between these young intellectuals and Luiz Moutinho, the head of the Brazilian diplomatic mission in France at the time, led to their abrupt return to Brazil and the discontinuation of their project after publishing only two volumes. In Brazil, however, all three editors would continue their intellectual careers, becoming important figures in Brazil's political and intellectual life and participating in the Instituto Histórico e Geográfico Brasileiro. Founded in 1838, the Instituto Histórico e Geográfico Brasileiro continued the project of intellectual modernization proposed by Nitheroy and its editors, although this project was now aligned with the central Imperial government through different forms of state patronage.

Nitheroy's critique of colonialism, essential to the project of constructing a Brazilian national identity, becomes clear in the texts on economics. Torres Homem's essay on slaveryleaves no doubt as to the critical tone Nitheroy assumes when reading Brazil's colonial period:

\footnotetext{
Quando vieram os cristãos do século XVI estabelecer-se na América, aonde deviam semear os germes da vindoura civilização, e associar os destinos do novo aos do antigo hemisfério, assinalaram sua presença por todas as calamidades, e horrores, de cuja comitiva andava a conquista naquelas eras constantemente ladeada: por estranho jogo das cousas humanas teve o gênio do mal larga parte em movimento tão rico de futuro, de potencia, e de civilização. (I, 35)
}

Torres Homem sees in the colonizers, and in their choice of slavery as the principal means of production for the colony, one of the burdens that Brazil, now an 
independent country, must fight and overcome. The marks left in Brazil by the Iberian settlers are the "calamidades e horrores" that they committed. The text continues by describing the negative economic effects of slavery, and basing its argument on English political economy, it defends free labor. Though Brazil would continue to depend on slavery for its work force after independence and would only end it officially in 1888 , Torres Homem explicitly blames the Portuguese and avoids connecting the issue to the local elites that also profited from slavery. A harsh critique of the colonizer runs throughout the magazine and reads as a relatively easy way to defend Brazil's recently gained political independence. In an article about sugar production, published in the second volume of the magazine and signed by several authors, the criticism against the colonizer and the necessity to overcome the colonial past is even more harshly stated:

O Brasil fora colônia, a corte de Lisboa prostrou, e mutilou com incansável rigor seu desenvolvimento agrícola ... e quando esta corte degenerada achou asilo neste mesmo Brasil, alvo outrora do seu ciúme, e das suas exações, não se podia esperar, que mudasse de sistema e, de repente iluminada, fizesse no novo mundo, de que possuía tão grandioso quinhão sem se dignar estudá-lo, aquilo que não fizera para seu território do antigo hemisfério, objeto das suas preferencias, e saudades. (II, 139)

Torres Homem casts the Portuguese, "esta corte degenerada," in a negative light and blames them for the country's backwardness. Now independent, he goes on, Brazil should speedily modernize itself towards its intrinsic and natural greatness. The same attitude can be seen in the period throughout Latin America, regardless of each country's immediate choice for monarchism or republicanism, where elites were simultaneously trying to distance themselves from their former colonial metropoles and defend their national independence. This stance is emblematic of the period, and not particular to Nitheroy. We may take, for instance, the Argentine literary critic and politician Juan María Gutiérrez (1809-1878), a contemporary of the Nitheroy editors. For him, the colonial period was marked by "el poder de la iglesia, única y universal, concentrado en un príncipe de tres coronas, y el de los reyes y emperadores, se 
daban la mano para robustecerse recíprocamente, y nadie era osado a pensar ni a obrar sino con ciega sumisión a la voluntad y al interés de aquellas monstruosas entidades" 'the power of the only and universal Church, centered in a prince with three crowns, and the power of kings and emperors, fortifying each other. No one would dare to work and think against their interests, moving always with blind submission to the will and interest of these monstrous entities' (76). Like Torres Homem and the other editors of Nitheroy, Gutiérrez was highly critical of the evils of the colonial period and, through his writing, he worked urgently to distance Argentina from Spain.

Together with the disdain for the colonizer and the criticism of the colonial administration, Nitheroy expresses a desire to find new commercial and cultural allies for Brazil. The most obvious choice for the magazine's editors is France, the cultural capital of the period and the site where the magazine itself was published. The influence of French thought in Brazil was not a novelty. ${ }^{3}$ In addition, some of the editors of the magazine had attended the Escola Real de Ciências, Artes e Ofícios in Rio de Janeiro, which was founded by Dom João VI to receive the French artistic mission of 1816 and which, after independence, became responsible for the iconography of the new country. For the Brazilian painter Araújo Porto-Alegre, a disciple of the French painter Jean Batiste Debret (1768-1848), studying at the school was central to his move to Paris and participation in Nitheroy. The Escola Real de Ciências, Artes e Ofícios had a precarious relationship with the government (Schwarcz, O sol do Brasil), and so it was never a political player in the independence process; in fact, it consistently followed established guidelines and trends, and as late as 1836 it still largely subscribed to the neoclassical aesthetics of Napoleonic France. Thus, it would take going to France for these young intellectuals to discover a more radical (or Romantic) voice and aesthetics that might give political meaning to their French affinities. Their relation to and interest in the French Revolution would, as previously mentioned, remain circumstantial and unresistant to the cooptation of their movement by the Imperial Brazilian government. In Nitheroy, nonetheless, the call for a strong relationship with France presents a political turn connected to the independence movement of 1822 and goes beyond the realm of ideas into areas that, during the colonial period, were part of the monopoly of the European metropole. 
Torres Homem's "Comércio do Brasil," published in the second volume of the magazine, calls for greater commercial relations between Brazil and France. For him, the relationship between the two countries, because of the colonial restrictions historically imposed by Portugal, "andam á dimensões bem pouco naturais," and he continues to propose closer ties:

\begin{abstract}
O mar, que as duas nações separa, devia pois abundar em navios indo, e vindo de uma à outra plaga, para trazer à cada uma d'elas os produtos apropriados à suas necessidades, e serrar os liames de amizade, e aliança, tornando-as ambas tributarias uma da outra por considerável porção dos seus gozos, e riquezas. (II, 150)
\end{abstract}

What Torres Homem suggests is the correction of the commercial imbalance that was created between Brazil and France after Napoleon invaded Portugal, when Brazilian ports were opened only to its "friendly" nations, leaving France excluded from commerce with Brazil until the end of the war. The same emphasis on France can be seen in Azeredo Coutinho's essay on sugar production. When talking about different boilers for sugar making, he suggests the use of boilers that "fabricam-se em França" (II, 65), explaining how Brazilian farmers can acquire these boilers, and once again privileging France as a commercial partner for Brazil. This move helped the editors of Nitheroy affirm the country's independence from Portugal, even if in so doing they were aligning themselves with another European power. This praise for France was not limited to Nitheroy (or to Brazil for that matter); rather, it was important throughout Latin America, though it manifested itself in different political tones within different countries, depending on the particular political situation and stability of each, or its affinity to the Ancien Régime or to republicanism. Upon achieving political independence, several South American countries in fact turned towards France in order to distance themselves from their Iberian colonizers while still claiming a "European" civilizational project. France was for this generation of Latin American intellectuals the "centinela avanzada del mundo intelectual" 'advanced sentinel of the intellectual world' (141), according to the Argentine writer Juan Bautista Alberdi (18101884), and a natural ally against Portuguese and Spanish influence. 
In addition to its critique of colonialism and the choice of new allies, Nitheroy proposes the modernization of Brazil, and more specifically, of the Brazilian economy. This meant, for nineteenth-century Brazil, following a European teleological notion of progress. As Torres Homem writes, "o carro tem de passar, e tem de passar, por que obedece em seu curso a uma lei infinitamente mais forte, que a vontade dos recalcitrantes, a Lei do progresso, e da civilização" (I, 39). To modernize the country and improve its deficient infrastructure was a way of catching up with Western European nations. "O rico lavrador," he writes, "envia o filho estudar nas capitais ilustradas da Europa não ciências, que relação tem com a agronomia, e lhe prestam indispensáveis luzes, mas sim aquelas, á que os prejuízos, e o desprezo da indústria soem dar certo verniz de aristocracia" (I, 79-80). The Brazilian elites, immersed in what Sergio Buarque de Holanda came to define as bacharelismo, saw their education (mostly in law) as status markers and, according to Torres Homem, did not use their time abroad to bring technical advancement to Brazil. The same discourse of modernization informs other texts in the magazine, such as the three essays on the production and commerce of sugar, nineteenth-century Brazil's main agricultural commodity. For Nitheroy and its contributors, Brazil was inefficient and wasteful, and because of the vices it had carried from the colonial period, it was not competitive enough in the global market. Their goal was, in part, to help seed this desire for modernization and improvement among the Brazilian elites, putting the country on a path towards development: "semear no seu paiz os conhecimentos e progressos das sciencias, das artes, e da industria" (89). As the Argentine poet Esteban Echeverría would write in a similar context a year after the publication of Nitheroy: "es cierto que la revolución, rompiendo el vasallaje y derribando las murallas que nos separaban de la Europa civilizada, nos abrió la senda del progreso y puso a nuestra disposición todas las teorías intelectuales" 'it is clear that the revolution, breaking the bonds of vassalage and tearing down the walls that separated us from the civilized Europe, also opened the path towards progress and made available to us all its different intelectual theories' (157). Technical development and progress was, in nineteenth-century Latin America, an important element for the consolidation of each country's national independence and was, as well, an 
obsession of the national elites, who were trying to adapt to their new political roles, both locally and internationally.

The fourth nationalistic theme present throughout Nitheroy is the necessity to think about the newly independent Brazil within its own specificities. In other words, this is the desire to explore and capitalize on what is autochthonous to the country. Europe, however, was still the teleological model for the country's modernization and better understanding of itself. As Torres Homem points out: "[a] Deus não praza, que ao Brasil proponhamos o exemplo Britânico: a profunda diferença das circunstancias de uma, e outra nação acarretaria a mesma diferença nos resultados, diferença, que só poderia desconhecer quem sobre as espaduas trouxesse uma cabeça de louco" (I, 38). For these young intellectuals, Brazil should not merely copy Europe, but rather invest in its own original qualities. As Magalhães writes in his essay on religion: "Eis aí o Brasil. Olhai, e examinai-o bem, estudai o seu caráter, e vede sua ideia dominante" (II, 30). The necessity to study the country on its own terms and to respect its specificities was a common concern across the continent in the nineteenth century. According to Alberdi, Latin America should aim towards: "una educación análoga y en armonía con nuestros hombres y con nuestras cosas; y si hemos de tener una literatura, hagamos que sea nacional, que represente nuestras costumbres y nuestra naturaleza, así como nuestros lagos y anchos ríos sólo reflejan en sus aguas las estrellas de nuestro hemisferio" 'an education that is analagous and in harmony with our men and things; and if we need to have our own literature, lets make it a national literature that represents our habits and nature, just as much as our lakes and broad rivers reflect the stars of our own hemisphere in their waters' (146). In the shadow of French Romanticism, intellectuals throughout the Americas were trying to understand how the region's particular geography, climate, nature, and history influenced development and differentiated American nations both from one another and from Europe, be it in the sphere of literature or in other areas, such as economics and political sciences (Candido, 289-95).

These four aspects of Nitheroy-its critique of colonialism, its turn towards France, the will to modernize Brazil, and the necessity to pay closer attention to the country's specificities-comprise the political framework of 
that generation. What is important to note, however, is that these same aspects are also central to Magalhães's Romantic manifesto, published in the same magazine. Thus, Magalhães's manifesto must be seen as a part of this interdisciplinary body of early nineteenth century nationalistic texts, and not only as a self-standing literary essay. In other words, Magalhães's manifesto should not be seen simply as an aesthetic manifesto, but also as a political one. Like the other texts published in Nitheroy, Magalhães's is clearly part of the postindependence political struggles faced by the Brazilian elites, and their call for the modernization of the country. In his manifesto, Magalhães, like Torres Homem, is quick to condemn colonialism: "o Brasil descoberto em 1500, jazeu três séculos esmagado de baixo da cadeira de ferro, em que se recostava um Governador colonial com todo o peso de sua insuficiência, e de sua imbecilidade" (I, 138). In doing so, he does not hesitate to condemn colonial Brazilian letters ("que chegadas a América não perderam seu caráter Europeu" (146)) while proposing a new Romantic paradigm. Like his peers, in order to fight the negative influence of Portugal and the consequences of colonialism, Magalhães also suggests turning towards France, the homeland of his main literary and philosophical influences-Madame de Staël, Victor Cousin, Chateaubriand etc.: "Com a expiração do domínio Português, desenvolveram-se as ideias. Hoje o Brasil é filho da civilização Francesa; e como Nação é filho desta revolução famosa, que balançou todos os tronos da Europa, e repartiu com os homens a púrpura, e os cetros dos Reis" (149). The modernization of Brazil and, more specifically, of its literature, is also a point emphasized by Magalhães, and the same notion of progress expressed by Torres Homem can also be seen in the former's manifesto: "Marchar para uma nação é engrandecer-se, é desenvolver todos os elementos da civilização" (144). And, in the case of literature, Magalhães points towards the necessity of leaving behind neoclassical paradigms and moving Brazilian literature toward a version of French Romanticism. His emphasis on "Indianism," for instance, depends on both Chateaubriand and Ferdinand Denis (1798-1890), two French Romantics who explored the aesthetic potential of the "exotic" Native Americans in the early nineteenth century. It is this exoticism, together with its climate and geography, that for Magalhães marks the specificity of Brazil and should be explored by Brazilian 
literature: "cada povo tem sua Literatura, como cada homem o seu caráter, cada árvore seu fruto" (132). Finally, all these elements, for Magalhães as well as for the rest of Nitheroy's authors, are intrinsically connected to the independence of Brazil, the "grito unânime dos corações Brasileiros ávidos de Liberdade, e de Progresso" (150), and they are clearly part of the national imaginary and ideology that the Brazilian elite and Nitheroy disseminated after independence. And that, with the Instituto Histórico e Geográfico Brasileiro, became the official discourse of the empire and a central element of national ideological (and territorial) cohesion.

Placing Magalhães's text side-by-side with the other essays from Nitheroy helps us better contextualize early Brazilian Romanticism. All the central topics and movements proposed by Magalhães are not merely literary concerns but are imbricated in the political debates in Brazil and the rest of Latin America after independence. Magalhães and early Brazilian Romanticism rose from the same political concerns of the Brazilian elites at the time and participated in their efforts to defend the country's independence and unity. When juxtaposed with other texts from Nitheroy, it becomes clear that the primary force behind Magalhães's manifesto is political rather than aesthetic. This does not mean that aesthetic considerations were not important to Magalhães; rather, it means that these considerations were a function of his nationalism. Romantic aesthetics, and the emphasis in Latin America on an exuberant and sublime nature, for instance, are certainly concerns Magalhães shares with other early Brazilian Romantics, and it can be seen even in texts published in Nitheroy that are not directly concerned with literature. The Romantic imaginary was available to all the writers in the magazine, and was used to argue their different points and the country's independence and peculiarity, not to mention its promising destiny. The opening of Azeredo Coutinho's article on comets with a "pitoresco quadro" (I, 7) and the Humboldtian description of an exuberant tropical tableau leaves no doubt regarding the influence Romantic aesthetics had on Nitheroy's generation. Nonetheless, the division and specialization that was already present, for instance, in certain currents of German Romanticism, was not feasible in Brazil, where aesthetic, literature, philosophy, and politics were all being thought and written about by the same intellectuals who were 
working towards the political goals of constructing an independent and united national state. That is, the main concern of early nineteenth-century Romantic generations in Latin America was to consolidate their countries' political and cultural independence rather than start an aesthetic revolution.

Several critics have already sketched the relation between Brazilian Romanticism and politics, but the dimensions of these connections and their comparative possibilities need to be better explored. Antonio Candido, for instance, has pointed out that early Brazilian Romanticism was influenced by nationalism and had politics in mind as much as aesthetics. "O Romantismo no Brasil," he writes, "foi episódio do grande processo de tomada de consciência nacional, constituindo um aspecto do movimento de independência" (312). Looking at Nitheroy in its totality leaves no doubt regarding this point, and as one continues to follow the development of Brazilian Romanticism, the political aspect of this literary movement seems to remain at its center for most of the nineteenth century. With the founding of the Instituto Histórico e Geográfico Brasileiro, as Schwarcz has shown (As Barbas do Imperador; O sol do Brasil), Brazilian Romanticism, and Magalhães himself, became part of the government's effort to justify itself, while a nationalistic version of the literary movement was turned into state policy, leading to the reconsideration and softening of the movement's more radical positions.

Reintroducing the centrality of politics into our analysis of Brazilian Romanticism can also help us relate Brazilian Romanticism to nineteenth-century literary movements elsewhere in Latin America, which have been studied as primarily political (Amante; Myers; Sommer). Early nineteenth-century literature in Latin America has consistently been connected to the building of each particular nation state. The Argentine case, with Domingo Faustino Sarmiento (1811-1888), Bartolomé Mitre (1821-1906), Alberdi (1810-1884), and others is emblematic. As Jorge Myers points out:

Férreamente ligado al proyecto de construcción de una identidad nacional, el Romanticismo literario ... demarcó un espacio estético menos rico en matices y contradicciones que en el caso de los Romanticismos europeos, y en cuyo interior la defensa del rol de la imaginación del artista debía ser 
relegada a un discreto segundo plano, así como todas la tendencias genéricas-como el gótico o la lírica erótica-que parecían distraer del propósito primordial que se asignaba a esa nueva literatura. (306)

In other words, Romanticism in Argentina was, above all, a political movement and the aesthetic decisions and choices in this movement were a function of that country's political struggles. Although the Brazilian choice of monarchism over republicanism, along with the different relationship each government established with its cultural elites, certainly pulled the Brazilian and Argentine movements in different directions, the necessity to consolidate their independence and to propose an enlightened national project out of colonialism remains an important point of contact that can allow for comparisons between the two countries. In nineteenth-century Argentina, like in Brazil, literature was a central part of the national political debate and used by intellectuals to advance their own political and educational agendas. And indeed, the third part of Sarmiento's Facundo, "Gobierno unitario" 'Unitarian Government' and "Presente y porvenir" 'Present and future, where Sarmiento explicitly connects the violence of Facundo Quiroga and the Argentine dictator Juan Manuel Rosas (1793-1877), a political enemy of Sarmiento when the book was published in 1845 , testifies to the book's political import. Sarmiento explicitly offers his own propositions for a new government, placing his essay and Romantic inclinations in the service of a political project. As Doris Sommer has shown, in Latin America "literature took its engagement with politics for granted" (73), and this took place both by supporting and criticizing official state projects. The confirmation of continental independence and the formation of independent nations, at least for these early generations of Romantic writers, were the central concerns of literature-a given that required no discussion. Writers were, according to Sommer, "integrated into partisan struggle" (4) and used their writings to advance their particular political positions, becoming a central element in the founding of their independent nations. This also emerges through a more extensive reading of Nitheroy; and if Brazilian Romanticism, due to its intellectuals' close relationship to the government and to the Instituto Histórico e Geográfico Brasileiro, turned out less combative or politically 
explicit, it is only because their project developed in closer proximity to the official project than in Argentina, and not because Brazilian Romanticism was less political or more autonomous.

Reading Nitheroy in all of its variety, and not only because of Magalhães's literary manifesto, allows us to place Brazilian Romanticism closer to other nineteenth-century literary movements in the Americas. That is, it presents Brazilian Romanticism as part of a larger political movement in search of nationhood. Considering Brazilian Romanticism as political, then, is an important step in no longer looking at Brazil as an island within Latin America, that is, as an exceptional Lusophone and monarchic case that does not seem to follow the same pattern of other countries in the region. Brazilian Romanticism in fact shares fundamental political concerns with other Latin American literary movements. The two volumes of Nitheroy indicate that much like Argentine Romanticism, early Brazilian Romanticism was chiefly a political movement. Moreover, once the traditional separation between Brazil and Hispanic Latin America is bridged and their similarities acknowledged, the differences between nineteenth-century Brazil and the Spanish-speaking part of the region might become of interest again, though for another reason. In this context, they would be seen in a new comparative light that might help us understand not only the individual national cases, but also, and more broadly, the peculiarity of literary and ideological forms and processes in the "periphery of capitalism" (Schwarz). 


\section{Notes}

1 I presented an earlier and shorter version of this argument in the panel "Capital Forms in Latin American Magazines," organized by Prof. Maria Blanco and Prof. Claire Lindsay, at the ACLA meeting in March 2014. I thank all the participants for their insightful comments and suggestions. Furthermore, I would also like to thank my colleague Adi Gold and Prof. Luiz Valente for proofreading my English and for making valuable suggestions for the improvement of this essay.

2 The reduction of Nitheroy to Magalhães's essay and to a literary magazine can be seen in important works of Brazilian literary history, such as Bosi 106-108; Candido (especially chapter 9); Coutinho 17-23; and, more recently, Moreira 54-92.

3 See, for instance, the well-known relationship between Brazilian Arcadismo and French eighteenth-century thought (Holanda 205-10; Candido 249-55).

\section{Works Cited}

Alberdi, Juan Bautista. "Doble armonía entre el objeto de esta instituición, con una exigencia de nuestro desarrollo social; y de esta exigencia con otra general del espíritu humano." El salón literario. Ed. Félix Weiberg. Buenos Aires: Hachette, 1958. Print.

Amante, Adriana. Poéticas y políticas del destierro: Argentinos en Brasil en la época de Rosas. Buenos Aires: Fondo de Cultura Económica, 2010. Print.

Bosi, Alfredo. História concisa da literatura brasileira. São Paulo: Cultrix, 1970. Print.

Candido, Antonio. Formação da Literatura Brasileira. Rio de Janeiro: Ouro sobre Azul, 2007. Print. Coutinho, Afrânio. A tradição afortunada. São Paulo: EDUSP/José Olympio, 1969. Print.

Echeverría, Esteban. "Primera Lectura." El salón literario. Ed. Felix Weimberg. Buenos Aires: Hachette, 1958. Print.

Gutiérrez, Juan María. Escritos históricos y literarios. Buenos Aires: Jackson, 1945. Print.

Holanda, Sergio Buarque de. Capítulos de Literatura Colonial. São Paulo: Brasiliense, 1991. Print. Lacoue-Labarthe, Philippe, and Nancy, Jean-Luc. The Literary Absolute. Trans. Barnard and Lester. Albany, NY: SUNY Press. 1988. Print.

Moreira, Maria Eunice. Nacionalismo literário e crítica romântica. Porto Alegre: IEL, 1991. Print.

Myers, Jorge. "Aquí nadie vive de las belas letras: literatura e ideas desde el salón literario a la organización nacional." Historia crítica de la literatura argentina. Ed. Noé Jitrik. Buenos Aires: Emecé, 2003. Print.

Nitheroy, revista brasiliense: sciencias, lettras, e artes. 1836. 2 vols. São Paulo: Academia Paulista de Letras, 1978.

Pinassi, Maria Orlanda. Três Devotos, uma Fé, nenhum Milagre: Um Estudo da Revista Niteroi, 1836. São Paulo: UNESP, 1998. Print.

Sarmiento, Domingo Faustino. Facundo. Buenos Aires: Gradfico, 2007. Print.

Schlegel, Friedrich. Lucinde and the Fragments. Trans. Peter Firchow. Mineapolis, MN: U of Minnesota P, 1971. Print. 
Schwarcz, Lilia Moritz. As barbas do imperador: d. Pedro II, um monarca nos trópicos. São Paulo: Companhia das Letras. 1998. Print.

- O sol do Brasil. Nicolas-Antoine Taunay e as desventuras dos artistas franceses na corte de d. João. São Paulo: Companhia das Letras. 2008. Print.

Schwarz, Roberto. Ao vencedor as batatas: forma literária e processo social nos inícios do romance brasileiro. São Paulo: Editora 34. 2000. Print.

—. Um mestre na periferia do capitalismo. São Paulo: Duas Cidades, 1990. Print.

Sommer, Doris. Foundational Fictions: The National Romances of Latin America. Berkeley: U of California P, 1991. Print.

\author{
Marcelo F. Lotufo is a $\mathrm{PhD}$ candidate in \\ Comparative Literature at Brown University. His \\ research focuses on Latin American intellectual \\ history and early nineteenth-century Brazilian and \\ Argentine literature. He has published articles in \\ Hispania and Arte 21, and he has also published \\ several reviews in Brasil/Brazil.
}

